\title{
Research on the Problems on Current Higher Vocational College Major Construction
}

\author{
Jing Jiang ${ }^{1}$ \\ ${ }^{1}$ Liaoning Police College, Dalian, Liaoning, 116036 \\ hunter2011@foxmail.com
}

Keywords: Higher Vocational College; Major Construction; Problems

\begin{abstract}
In recent years, the state attaches great importance to vocational education, through continuous reform and innovation, vocational education becomes clearer direction of running, training mode is more flexible, more prominent occupational characteristics, training of personnel and more widely recognized by society. But the quality of personnel training and practical needs still have gaps, graduate students' knowledge structures and competencies and the employer requires have a gap, a direct factor is the major course construction and curriculum development issues this gap. This article will reveal the professional construction and curriculum development problems in higher vocational colleges and provides a reference for professional development and curriculum development.
\end{abstract}

\section{Introduction}

Currently, more prominent issue higher vocational colleges in the professional construction and personnel training process, is facing is the quality and the actual needs of personnel training, there are still some gaps, graduate students and competency requirements knowledge structure and there are still some employers distance, have a direct factor is the construction of vocational colleges issue this gap.

\section{The Main Question}

Professional Settings and for Economic and Social Industry of Touch. In recent years, colleges and universities increased school autonomy, many vocational colleges in pursuit of economic efficiency, in the professional setting, often ignoring the existing school conditions, not pay attention to the social demand for research, and even to the country industrial policy ignorant, lack of scientific expertise and effective demonstration and prediction mechanism, there is no dominant industry trends not only with the local economy to adapt, but also based on their own school conditions and characteristics to practical professional development plan, in actual work is often expressed as:

The lack of understanding of the economic and social needs of the industry, I do not know what the new bid for a professional, there is no clear direction and goals, not with the times;

Only from the point of view in favor of admission, regardless of their condition blind bid for some of the "hot" professional, generous, this professional blind setting, it is difficult to form a competitive advantage, but also caused great waste of educational resources ;

The lack of transformation and upgrading of traditional professional, very difficult to "abandon";

New, edge, crossing campus-wide (department), disciplinary professional bid is not enough, lack of stamina specialty construction and development.

This makes professional nationwide Polytechnics disorganized, lack of features, follow the trend of serious, professional "homogeneity" problem widespread, resulting in duplication popular professional, professional set of large and small and complete, professional and construction "bright spots" not outstanding.

Professional Development also Left the Imprint of Planned Economy and A Lack of Awareness. With the reform, the upper end of the century the state canceled the "graduation assignments" policy, the implementation of two-way choice of employment policy. But to some 
extent, despite the "sales" of the problem it has been pushed to the market, but the enrollment plan, approval, and other professional education are still controlled by the government administrative departments.

At the same time, many employees of the Higher Colleges of higher vocational education educational philosophy, direction lack of knowledge, professional development of vocational connotation lack of deep understanding, leaving the stigma of the planned economy on professional development, the major construction and regular undergraduate Higher The disciplines confused, followed the pattern and methods of undergraduate disciplines of colleges, professional construction target is not clear, the idea is not clear enough, and content material and some even declared are not very clear, not to mention the students to develop into what kind of person, how to train. In particular, a new set of professional, but also on the teaching reform, it is still difficult to get rid of the concept of curriculum system on the impact of general disciplinary system curriculum, curriculum reform in the first state. There are also some professional, at first on the basis of curriculum reform to proceed into the second reform, in spite of the pre-reform remarkable achievements, but because of the rapidly changing industrial structure adjustment and professional positions, many elements of the course is relatively old, knowledge Renewal and materials lag increasingly prominent contradiction, did not make a long-term presence of Curriculum and Textbook "dynamic development" process, make some career field use new knowledge, new technologies can not be reflected in teaching, thereby affecting the higher vocational education for the production, construction, service and management training of highly skilled frontline personnel to achieve the goal of better, which severely restricted the development of vocational education.

Lack of Professional Support Conditions, Faculty and Training Base is The Weak Link. Teachers respect. Teachers are the main force of professional development and education, but also the construction of the main object, but since most vocational colleges are upgraded from a secondary school or vocational big improvement from the merger, teachers generally weak, although many vocational In recent years, colleges and universities with the continued expansion of enrollment, to resolve the shortage of teachers from colleges to introduce a large number of young teachers, but less line transferred from the practice, and they do not have business experience, have little contact with the actual production, you can not really grasp the business skills and requirements, practical ability is relatively weak, relatively speaking. Therefore, teachers structure is irrational, teaching ability is not strong and "double" a serious shortage of quality teachers' situation will exist in a considerable period.

The training based construction. Training Base is an important place for students to cultivate career awareness, career emotional and professional competence, but also the construction of vocational colleges focus. Since vocational training is for production, management, operation and services applied talents of the first line, it must have a good training base to meet the graduates ideal "zero distance" employment. In recent years, due to the large number of additional new professional and enrollment, leading to school funding tight, practical training base construction is difficult to place in time, it is difficult to update equipment, which is the practice of teaching, especially teaching a greater interference. The training base outside because of the lack of policy support, enterprises are worried that affect product quality or economic rather than allow students internships, coupled with some joint ventures or foreign-funded enterprises since the "technological secrets" of factors difficult to implement student internships, resulting in most high vocational schools are not stable off-campus training base, although some units because of the sensibilities of students accepted, but are often just go, it is difficult to achieve the desired teaching objectives. It can be said, has become a training base construction is lagging behind the constraints of professional construction and development of higher vocational colleges biggest "bottleneck", is currently difficult to deepen the reform of vocational education and "professional" features important reason is not obvious. 


\section{Cause Analysis}

Mistakes in Understanding. Specialty Construction in Vocational reason, there are still many problems, the most fundamental reason is the lack of awareness of many people vocational education, and even the existence of significant errors.

Vocational schools and vocational education clear understanding. Vocational training for the community colleges is mainly applied a variety of high-quality skilled personnel, therefore, teaching vocational education is a kind of lateral-based modular teaching system, its core elements are the special skills of professional positions and operability as the basis for students with solid professional skills, specifically deep post business knowledge, strong technical reproducibility as the goal. In teaching methods, practice teaching hours of vocational education generally accounted for about $50 \%$ of the total hours of teaching programs, experimental teaching plan prescribed training courses out rate should be above $90 \%$; every professional must have in the school appropriate skills training, simulation operation sites and stable off-campus practice base practice. Practical teaching is an important way to cultivate vocational students' professional ability, technology and innovation ability, reflecting the characteristics of applied vocational talents training.

The relevant theoretical study of professional settings is lack of scientific theory. With college enrollment began in 1999, vocational education has entered a stage of rapid development. In professional settings aspect many people have raised the need to get rid of the traditional higher professional education in professional settings according to the undergraduate disciplines mode approach, stressing that according to the training objectives of higher vocational education, for the needs of regions, sectors of economic and social development, according to technical fields and professional positions (group) is required to set and adjust the actual professional, but also set a more professional autonomy underground into the school. These initiatives has yielded good results, but also led to the emergence of the aforementioned problems, the most direct consequence of lack of stamina professional development, recruitment, employment situation is not ideal. In fact, professional setting depends mainly on three factors: demand factors determined by the labor market; supply factors determined by the education market; educational resources factors conditions determined by the school running. Any one factor changes, will affect the specialty colleges.

Personnel Training Is Unclear. Director of the Department of Higher Vocational Education at the National Vocational Fan Wei Rectors' Conference at the seventh plenary meeting mentioned, the starting point of the current school vocational education must return to the training of highly skilled personnel standard up, if you leave this out, it can not become a Higher Vocational true sense of the word. This requires us to improve the quality of education (especially the quality of personnel training) Higher included professional development goals and planning. But in recent years, many vocational colleges for talent fostering a clear understanding, ignoring the relationship between professional development and personnel training, and the promotion of professional development as the primary goal of professional development, professional bent on bigger and stronger, Enrollment continues to expand the scale, without taking into account the starting point and destination point if taking into account the professional development of students 'professional needs and personal development, meets the cultivation of students' individual comprehensive ability. It is because of this positioning is unclear, so a lot of the training objectives of higher vocational education for the blind reference to general higher education, have higher education to the general line, and even training objectives of convergence, coupled with the students poor foundation, educational soft low hardware level, so that the higher vocational colleges trained personnel, either in theory or in the education level is not as high-level graduates of ordinary institutions of higher learning, but also lost the characteristics of talent cultivation target, the ability and practical aspects of the operating capacity and even catch up with some of the secondary school graduates. So to carry out major construction should locate talent cultivation in higher vocational colleges, scientific positioning, locating social services to consider these three functions, otherwise there will be many problems mentioned above. 
Lack of Effective School-Enterprise Cooperation Mechanism. Vocational education training objectives determine the vocational education must take the road of combining production and research, professional development must also strengthen school-enterprise cooperation. But now, China Vocational College has not really formed school-enterprise cooperation mechanisms mutual win, school-enterprise cooperation difficult. There are three main reasons: First, the existing national policy is not sufficient to mobilize the industry, the enthusiasm of enterprises, insufficient investment in education, we can not provide similar Australian TAFE Mode "Training Package (TP)" as the authority of the professional schools standards, making arbitrary bias of school-enterprise cooperation; the second is the school's own lack of organization of students leave school to enter the financial business or institution, allows students to practice locations difficult to access funding guaranteed under the circumstances, many schools can only take so that students themselves Practice question the way so that students practice hard to get proper skills, and the strength and influence has far from vocational colleges can attract companies take the initiative to seek cooperation with the school to the point, so they appear in the school-enterprise cooperation school hot, cold embarrassment enterprise; Third, actively enterprise cooperation is not high has become a major obstacle to professional development Vocational get support of the majority of enterprises or other employers are not willing to accept the student internships, because once the students into internships on for these units increased the number of work and responsibility, as well as instructors to arrange internships and internships utensils site, if companies with no return way to accomplish these tasks, is basically impossible, only companies after accepting internship can be reserve talents reserve, this practice it may be subject to corporate welcome.

Lack of Appropriate Professional Development Evaluation Mechanism. Grim employment situation is one of the main current constraints in the development of vocational education, reasons include: weak social needs, lack of jobs; vocational graduates channel is not smooth; vocational graduates acquired skills are not well to meet the needs of the community; and students' employment expectations too high. Therefore, higher vocational colleges in the professional building must have a valid evaluation mechanism, adhere to the employment-oriented key consideration: professional setting whether social talent market effective demand for professionals in this match, graduate employment rate is high; talent Positioning is accurate training objectives, whether it can meet the requirements of employers, cultivate a high-quality technical and applied talent, both have some basic theoretical knowledge, but also have a high level of expertise and strong practical ability, effort be "competent employability, entrepreneurship has the ability to continue learning foundation"; teaching content, teaching methods and means to meet the requirements of reform vocational training objectives; and whether to carry out the reform of training model and way of innovation, such as conduct Cooperative Education colleges, enterprises, implementation of the "double certificates" system of education and teaching credit management system. Only with a good professional building assessment system, in order to avoid some problems, and it is generally lacking in many current vocational colleges.

\section{Conclusion}

In short, the vocational education program is a systematic project, is to meet the social needs of school personnel and a basic yardstick for community personnel to guide the consumer, the adaptation of vocational schools reflects the socio-economic development, science and technology development and the development of professional positions. Currently, major construction work has become the core of higher vocational colleges, professional construction of a direct impact on the enrollment of higher vocational colleges, the survival and development of employment and entrepreneurship training of students and graduates related to vocational colleges. It is the key to improve the quality of personnel training, a breakthrough to enhance the educational level of higher vocational colleges and to improve the social reputation of the focal point. Therefore, strengthening the theory and practice of construction in vocational colleges is very necessary and is the eternal theme of higher vocational education. 


\section{References}

[1] XuXiao J, Discussion the Practice of Construction in Vocational Colleges, Technological Innovation Herald, 2010 NO.29;

[2] Cai Jian, JianHua C, Problems In Specialty Construction of Vocational Colleges Exist, Vocational Education Newsletter, November 2005;

[3] ZhiRong G, Construction of Higher Vocational Institute and Causes of The Problems, Occupation Space, 2008 10;

[4] WenRong B, Zhen-Kun S, Major Construction in Higher Analysis and Exploration, Radio and TV University, 2012 Section 5;

[5] GuangHuan C. On The Professional Building Vocational Problems, A Network Of Wealth, In May 2009. 